\title{
Pathogen screening in the red fox (Vulpes Vulpes) from Lithuania
}

\author{
Povilas Sakalauskas, \\ Indrè Lipatova, \\ Jana Radzijevskaja, \\ Algimantas Paulauskas* \\ Vytautas Magnus University, \\ K. Donelaičio St. 58, \\ 44248 Kaunas, Lithuania
}

\begin{abstract}
The aim of this study was to screen free-ranging red foxes from Lithuania for the presence of different vector-borne pathogens. A total of 31 red foxes from three districts of Lithuania were molecularly tested for the presence of pathogens. Five different pathogens were detected in $83.9 \%$ of red foxes: Anaplasma spp., Bartonella spp., Rickettsia spp., Borrellia spp. and Babesia spp. The presence of Mycoplasma spp. and Dirofilaria spp. was not detected in our study.
\end{abstract}

Keywords: Vulpes vulpes, Anaplasma spp., Bartonella spp., Rickettsia spp., Borrellia spp., Babesia spp., Mycoplasma spp., Dirofilaria spp.

\section{INTRODUCTION}

The red fox (Vulpes vulpes) is the most widely distributed of all wild canids, with a natural range from the deserts to the Arctic tundra (Schipper et al., 2008; Edwards et al., 2012). The red fox is adapted to different environments and can easily survive in urban areas (Teacher et al., 2011; Scott et al., 2014). Living in close proximity to people may pose a risk in the case of the transmission of zoonoses and veterinary diseases (Truyen et al., 1998; Hodžić et al., 2015; Koneval et al., 2017; Víchová et al., 2018). Determining the impact of wildlife for pathogen transmission is important for epidemiological studies.

In the past, red foxes were most commonly associated with the epidemiological cycle of rabies (Chautan et al., 2000; Vos, 2003; Zienius et al., 2007). Also, several studies showed that red foxes are a reservoir for zoonotic parasites, such as Echinococcus multilocularis, Trichinella spp., and

\footnotetext{
*Corresponding author. Email: algimantas.paulauskas@vdu.lt
}

Toxocara canis (Saeed et al., 2006; BružinskaitèSchmidhalter et al., 2012; Franssen et al., 2014; Karamon et al., 2018). Recent studies have revealed that in Europe, red foxes are infected with vector-borne pathogens (Hodžić et al., 2015; Koneval et al., 2017; Hodžić et al., 2018).

A long-term rabies persistence period in the red fox populations was reported in Lithuania (Zienius et al., 2007). Other studies investigated zoonotic helminths of red foxes (BružinskaiteSchmidhalter et al., 2012; Janulaitis et al., 2014). However, the real role of the red foxes as a source of different pathogens is unclear. Therefore, the principal aim of this study was to screen freeranging red foxes from Lithuania for the presence of different vector-borne pathogens.

\section{MATERIALS AND METHODS}

\section{Collection of samples}

A total of 31 red foxes from three districts of Lithuania were included in the present study (Fig. 1). From 2016 to 2018, carcases of red foxes 


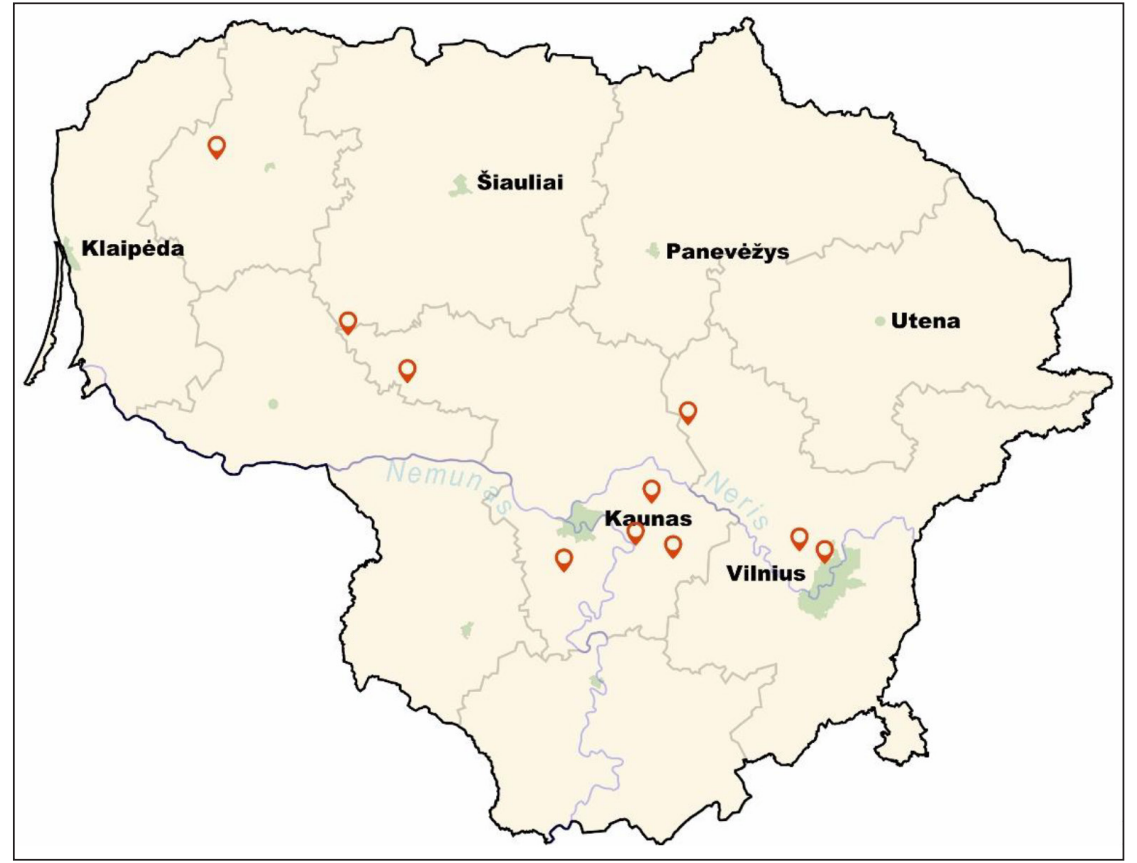

Fig. 1. The map of localities where red foxes were collected were collected in collaboration with hunters. The data on sex, the area of origin, and the hunting date were recorded for each individual red fox (Table 1). During necropsy, spleen samples were collected and frozen at $-20^{\circ} \mathrm{C}$ until DNA extraction.

\section{DNA extraction, PCR amplification}

DNA was isolated using the GeneJET Genomic DNA Purification Kit (Thermo Fisher Scientific, Lithuania) according to the manufacturer's instructions and stored at $-20^{\circ} \mathrm{C}$ for further analyses.

All DNA samples were screened for the presence of Anaplasma spp., Bartonella spp., Rickettsia spp., Borrellia spp., and Babesia spp. using multiplex real time-PCR assay. Primer sequences and target gene used in this study are presented in Table 2. RT-PCR reactions

Table 1. Sex of red foxes and their collection areas

\begin{tabular}{c|c|c|c|c}
\hline & Vilnius & Kaunas & Telšiai & Total \\
\hline \multirow{0}{*}{} & 3 & 12 & 0 & 15 \\
\hline+ & 3 & 12 & 1 & 16 \\
\hline Total & 6 & 24 & 1 & 31 \\
\hline
\end{tabular}

were done in total volume of $15 \mu$ consisting of $100 \mathrm{ng}$ of extracted DNA, (1x) SensiMix ${ }^{\text {Tx }}$ II Probe No-ROX (Bioline), $1 \mu \mathrm{M}$ of each primer, and $0.5 \mu \mathrm{M}$ of each probe. Cycling reactions started with an initial activation step of $95^{\circ} \mathrm{C}$ for $10 \mathrm{~min}$ followed by 45 cycles of $95^{\circ} \mathrm{C}$ for 20 s, $60^{\circ} \mathrm{C}$ for $60 \mathrm{~s}$ (for Anaplasma, Borellia, and Babesia) and $50^{\circ} \mathrm{C}$ for $60 \mathrm{~s}$ (for Bartonella ant Rickettsia), and $72^{\circ} \mathrm{C}$ for $20 \mathrm{~s}$. Cycling reactions were carried out using a Rotor Gene 6000 (Corbett Research, Australia).

Mycoplasma spp. and Dirofilaria spp. were detected using conventional PCR method. For Mycoplasma spp. were amplified 16S RNA region using 322s and 938as primers according Varanat et al. (2011). For filarial screening, pan-filarial primers (DIDR-F1, DIDR-R1) were used that amplify fragments of different length of the internal transcribed spacer region 2 (ITS2) of the ribosomal DNA from six different filarioid species (Dirofilaria repens, D. immitis, Acanthocheilonema reconditum, A. dracunculoides, Brugia pahangi and B. malayi). The PCR were conducted as described by Rishniw et al. (2006). All amplification products were electrophoresed on a $1.5 \%$ agarose gel and visualized under UV light after staining with ethidium bromide. 
Table 2. Primers used for the amplification of DNA of different pathogens

\begin{tabular}{|c|c|c|c|}
\hline Pathogen & Primer sequences & $\begin{array}{l}\text { Target } \\
\text { gene }\end{array}$ & $\begin{array}{l}\text { Length of amplicons } \\
\text { (bp) (reference) }\end{array}$ \\
\hline $\begin{array}{l}\text { Anaplas- } \\
\text { ma spp. }\end{array}$ & $\begin{array}{c}\text { 5'-GGACAACATGCTTGTAGCTATGGAA- } \\
\text { GG-3' } \\
\text { 5'-CCTTGGTCTTGAAGCGCTCGTA-3' } \\
\text { 5'-TCTCAAGCTCAACCCTGGCACCAC- } \\
\text { CA-3' VIC/BHQ1 }\end{array}$ & $m s p 2$ & 98 (Razanske et al., 2019) \\
\hline Bartonella spp. & $\begin{array}{c}\text { 5'AGTTGCAAATGACAACTATGCGG-3' } \\
\text { 5'-AAGGCTTCTGTTGCCAGGYG-3' } \\
\text { 5'-ACCCCGCTTAAACCTGCGACGGTT-3' } \\
\text { HEX/BHQ1 } \\
\end{array}$ & $s s r A$ & $\begin{array}{l}124 \text { (Mardosaité- } \\
\text { Busaitienè et al., 2019) }\end{array}$ \\
\hline Rickettsia spp. & $\begin{array}{c}\text { 5'-TGCMGAYCATGAGCACAATGCTTC-3' } \\
\text { 5'-CCCAAAGTGAKGCAATACCCGT-3' } \\
\text { 5'-TGCCGGCTCATCYGGAGCTAACCC-3' } \\
\text { FAM/BHQ1 } \\
\end{array}$ & gltA & $\begin{array}{l}338 \text { (modified from } \\
\text { Biernat et al., 2016) }\end{array}$ \\
\hline Borrellia spp. & $\begin{array}{c}\text { 5'-GCTTCAGCCTGGCCATAAATAG-3' } \\
\text { 5'-AGCGAGTCTTAAAAGGGCGATT- } \\
\text { TAGT-3' } \\
\text { 5'-TCACTCGGSTTCGGGTCTACCA- } \\
\text { CATCT-3' FAM/BHQ1 }\end{array}$ & $23 S r R N A$ & $\begin{array}{c}77 \text { (designed in this } \\
\text { study) }\end{array}$ \\
\hline Babesia spp. & $\begin{array}{c}\text { 5'-GACTCCTTCAGCACCTTGAGA-3' } \\
\text { 5'-GACCCCTTCAGGAGCTTGAGA-3' } \\
\text { 5'-CATGCACCACCACCCAWAGAATCA-3' } \\
\text { 5'-TGACGGAAGGGCACCACCAGGCGT-3' } \\
\text { ROX/BHQ2 }\end{array}$ & $18 S r R N A$ & $\begin{array}{l}214 \text { (Razanske et al., } \\
\text { 2019) }\end{array}$ \\
\hline $\begin{array}{l}\text { Mycoplas- } \\
\text { ma spp. }\end{array}$ & $\begin{array}{c}\text { 5'-GCCCATATTCCTACGGGAA- } \\
\text { GCAGCAGT-3' } \\
\text { 5'-CTCCACCACTTGTTCAGGTCCC- } \\
\text { CGTC-3' }\end{array}$ & $16 S r R N A$ & 600 (Varanat et al., 2011) \\
\hline Dirofilaria sp. & $\begin{array}{l}\text { 5'AGTGCGAATTGCAGACGCATTGAG-3' } \\
\text { 5'-AGCGGGTAATCACGACTGAGTTGA-3' }\end{array}$ & $\begin{array}{l}\text { 5.8S-ITS2- } \\
\quad 28 S\end{array}$ & $\begin{array}{l}\text { 484-542 (Rishniw et al., } \\
\text { 2006) }\end{array}$ \\
\hline
\end{tabular}

\section{Statistical analysis}

The prevalence of different pathogen infection analysis was performed using Mixrosoft excel software. The InteractiveVenn tool was used to create the Venn diagram and calculate coinfections (Heberle et al., 2015).

\section{RESULTS AND DISCUSSION}

In general, vector-borne pathogens were detected in $83.9 \%(26 / 31)$ of red foxes. Five different pathogens were detected: Anaplasma spp., Bartonella spp., Rickettsia spp., Borrellia spp., and Babesia spp. (Table 3).
The most prevalent pathogen in red foxes from Lithuania was Babesia spp. (20/31, 64.5\%). This pathogen was detected in all studied areas (Table 3). Females $(60.0 \% ; 12 / 20)$ were more infected with Babesia spp. than males (40.0\%; $8 / 20$ ). A number of studies reported that red foxes were infected with such Babesia spp. as B. canis, B. venatorum, B. vulpes (synonyms: $B$. microti, B. cf. microti, B. annae) (Karbowiak et al., 2010; Cardoso et al., 2013; Duscher et al., 2014; Najm et al., 2014; Farkas et al., 2015; Hodžić et al., 2015; Koneval et al., 2017; Hodžić et al., 2018; Baneth et al., 2019). Ticks are the main vector of this blood parasite. Several studies show 
Table 3. Infection with different pathogens in red foxes from Lithuania

\begin{tabular}{|c|c|c|c|c|c|c|c|c|c|c|}
\hline & \multicolumn{2}{|c|}{ Anaplasma spp. } & \multicolumn{2}{|c|}{ Bartonella spp. } & \multicolumn{2}{|c|}{ Rickettsia spp. } & \multicolumn{2}{|c|}{ Borrellia spp. } & \multicolumn{2}{|c|}{ Babesia spp. } \\
\hline & $\hat{0}$ & $q$ & $\hat{0}$ & q & 0 & o & 0 & q & $\hat{\jmath}$ & q \\
\hline Vilnius & $2 / 3$ & $2 / 3$ & $0 / 3$ & $3 / 3$ & $0 / 3$ & $0 / 3$ & $0 / 3$ & $3 / 3$ & $3 / 3$ & $3 / 3$ \\
\hline Kaunas & $6 / 12$ & $4 / 12$ & $2 / 12$ & $3 / 12$ & $1 / 12$ & $1 / 12$ & $3 / 12$ & $1 / 12$ & $5 / 12$ & $8 / 12$ \\
\hline Telšiai & - & $1 / 1$ & - & $0 / 1$ & - & $1 / 1$ & - & $1 / 1$ & - & $1 / 1$ \\
\hline Total & $8 / 15$ & $7 / 16$ & $2 / 15$ & $6 / 16$ & $1 / 15$ & $2 / 16$ & $3 / 15$ & $5 / 16$ & $8 / 15$ & $12 / 16$ \\
\hline
\end{tabular}

Numbers given in the table indicate the number of red foxes infected with pathogens/number of red foxes tested.

the presence of Babesia spp. in ticks (Ixodes hexagonus, I. ricinus) collected from red foxes (Najm et al., 2014; Checa et al., 2018).

Another tick-transmitted bacteria detected in our study was Anaplasma spp. A total $48.4 \%$ $(15 / 31)$ of the tested samples showed positive results. This pathogen was also detected in all the studied areas (Table 3). Infection of red foxes with $A$. phagocytophilum was reported from Poland (Karbowiak et al., 2009), Italy (Ebani et al., 2011), Germany (Härtwig et al., 2014), Croatia (Beck et al., 2014), Netherlands (Jahfari et al., 2014), Hungary (Tolnai et al., 2015), Romania (Dumitrache et al., 2015b), Switzerland (Hofmann-Lehmann et al., 2016), and Austria (Hodžić et al., 2018). A. ovis was reported in red foxes from Sicily (Italy) (Torina et al., 2013); A. bovis in Croatia (Beck et al., 2014); A. platys in Portugal (Cardoso et al., 2015). A. phagocytophilum has also been detected in I. ricinus ticks collected from red foxes (Dumitrache et al., 2015a; Víchová et al., 2018). Moreover, Torina et al. (2013) detected A. phagocytophilum, A. ovis, and A. marginale in fleas (Xenopsylla cheopis, Ctenocephalides canis) collected from red foxes.

Bartonella spp. are distributed in wild carnivores (Gerrikagoitia et al., 2012; Bai et al., 2016). Red foxes tested in this study were also infected with Bartonella spp. $(25.8 \% ; 8 / 31)$. These results are consistent with findings from other countries. There are some reports that infected red foxes carried B. rochalimae, B. v. berkhoffii, B. clarridgeiae (Henn et al., 2009; Kaewmongkol et al., 2011; Gerrikagoitia et al., 2012; Bai et al., 2016; Hodžić et al., 2018). Ectoparasites, such as fleas and ticks, play a role in the transmission of Bar- tonella species (Chomel et al., 2009). B. rochalimae was found in Pulex irritans fleas from red foxes in Spain (Márquez et al., 2009); B. henselae and B. clarridgeiae were detected in Ctenocephalides felis fleas from red foxes in Australia (Kaewmongkol et al., 2011). Bartonella spp. were found in fleas (Chaetopsylla globiceps, P. irritans, Ctenophtalmus assimilis) collected from red foxes in Slovakia (Víchová et al., 2018). The authors performed the obtained sequence analysis that showed identity or similarity to $B$. rochalimae and B. taylorii (Víchová et al., 2018).

Infection with Lime diseases pathogen Borrellia spp. was also found in studied red foxes from Lithuania $(25.8 \%(8 / 31)$. Previous studies reported that red foxes were infected with B. burgdorferi sensu lato (Isogai et al., 1994; Heidrich et al., 1999; Dumitrache et al., 2015b; Lledó et al., 2016; Mysterud et al., 2019). Data on the diversity of $B$. burgdorferi sl in red foxes present four species $B$. burgdorferi sensu stricto, $B$. afzelii, B. lusitaniae, and B. garinii (Isogai et al., 1994; Dumitrache et al., 2015b; Sukara et al., 2019). B. burgdorferi sl has also been detected in I. ricinus and I. persulcatus ticks collected from red foxes (Isogai et al., 1994; Dumitrache et al., 2015a).

The prevalence of Rickettsia spp. infection detected in the present study is of the lowest level $(9.7 \%$; 3/31). Other authors confirmed in serological studies that foxes were exposed to R. typhi, R. slovaca, R. conorii and R. massiliae/Bar29 (Lledó et al., 2016; Ortuño et al., 2018). R. helvetica was detected in foxes from Sweitzerland (Hofmann-Lehmann et al., 2016). Ortuño et al. (2018) reported that Rhipicephalus sanguineus complex ticks collected from red 
foxes were infected with $R$. massiliae, $R$. aeschlimannii, and $R$. slovaca (Ortuño et al., 2018). In France, arthropods collected from red foxes showed Rickettsia-positive results. Ticks (Rhipicephalus turanicus) were found to be infected with $R$. massiliae and fleas (Archaeopsylla erinacei) collected in the study contained $R$. felis (Marié et al., 2012). Also, R. felis was detected in fleas (Ctenocephalides felis) from red foxes in Sicily, Italy (Torina et al., 2013). R. massiliae DNA was detected in $R h$. sanguineus ticks collected from a fox in Sardinia, Italy (Chisu et al., 2017). Moreover, Víchová et al. (2018) reported that fleas (Archaeopsylla erinacei) and ticks (Ixodes ricinus, Ixodes hexagonus, Haemaphysalis concinna) removed from red foxes in Slovakia were infected with Rickettsia spp. (Víchová et al., 2018).

Mycoplasma is a genus of haemotropic, selfreplicating bacteria (Messick 2004). Most of them are responsible for a variety of diseases in humans, animals, insects, and plants (Sumithra et al., 2013). There is a lack of information about mycoplasma in wild animals. Moreover, only a few studies report the occurrence of mycoplasmas in red foxes (Kanamoto et al., 1981; Sasaki et al., 2008; Koneval et al., 2017; Millán et al., 2018). Mycoplasma spp. was not detected in any of the tested red fox spleen samples in this study. However, in a study in Slovakia, out of 300 samples of red foxes tested, Mycoplasma spp. bacteria was detected in $13(4.3 \%)$ (Koneval et al., 2017). Also, out of 12 red foxes, only one $(0.83 \%)$ was positive for M. haemocanis in Japan (Sasaki et al., 2008). A study in Spain showed 2.4\% (1/41) infection of Mycoplasma spp. in red foxes (Millán et al., 2018). Considering that studies from other countries have a very low infection rate of Mycoplasma spp. in red foxes, future screening of this pathogen is required with a largest sampling site in Lithuania. Also, ectoparasites (ticks, fleas) collected from red foxes in Slovakia were tested for the presence of $\mathrm{Myco-}$ plasma spp. but the infection was not detected (Víchová et al., 2018).

Dirofilariasis is recognized as a zoonosis spreading across Europe (Genchi et al., 2009;
Genchi et al., 2011; Simón et al., 2012). A previous study showed that $D$. repens is a zoonotic parasite in Lithuania (Sabūnas et al., 2019a). In Lithuania, nine human cases of $D$. repens during the period of 2011-2018 and the prevalence of $D$. repens among shelter dogs have been reported. Furthermore, recently $D$. immitis was found in an imported dog in Lithuania (Sabūnas et al., 2019b). Some researchers consider that free-living carnivores such as red foxes may act as a natural reservoir of zoonotic filariasis (Magi et al., 2008). Seeing that, in this study we analysed the spleen samples of red foxes from Lithuania for filarial infection in order to investigate their role as a potential wildlife reservoir of dirofilariasis. Of all tested foxes, none were positive for filarian parasites. However, D. repens infection in red foxes has been recorded in Italy (Marconcini et al., 1996; Magi et al., 2007), Slovakia (Hurníková et al., 2012), Serbia (Ćirović et al., 2014), and Romania (Ionică et al., 2017). Besides, heartworm (D. immitis) infection was found in red foxes in Italy (Marconcini et al., 1996; Magi et al., 2007), Spain (Mañas et al., 2005), Serbia (Penezić et al., 2014), Hungary (Tolnai et al., 2014), and Romania (Ionică et al., 2017). Otherwise, there are reports from other researchers that filariasis was not detected in red foxes (Hodžić et al., 2015; Härtwig et al., 2016; Hodžić et al., 2018). Considering that the distribution of filariasis in Europe is continuously spreading (Genchi et al., 2009; Genchi et al., 2011; Simón et al., 2012), future screening for filariasis in wildlife carnivores in Lithuania is required.

Majority of red foxes $(77.4 \% ; 24 / 31)$ were infected with more than one parasite species. Coinfections with two to four different pathogen species were observed (Fig. 2). Coinfection with two different pathogens were detected in 14 red foxes: one fox was infected with Babesia spp. and Borrelia spp.; one fox was infected with Babesia spp. and Rickettsia spp.; three foxes were infected with Anaplasma spp. and Borrelia spp; three foxes were infected with Babesia spp. and Bartonella spp.; six foxes were infected with Anaplasma spp. and Babesia spp. Coinfection with three different pathogens 


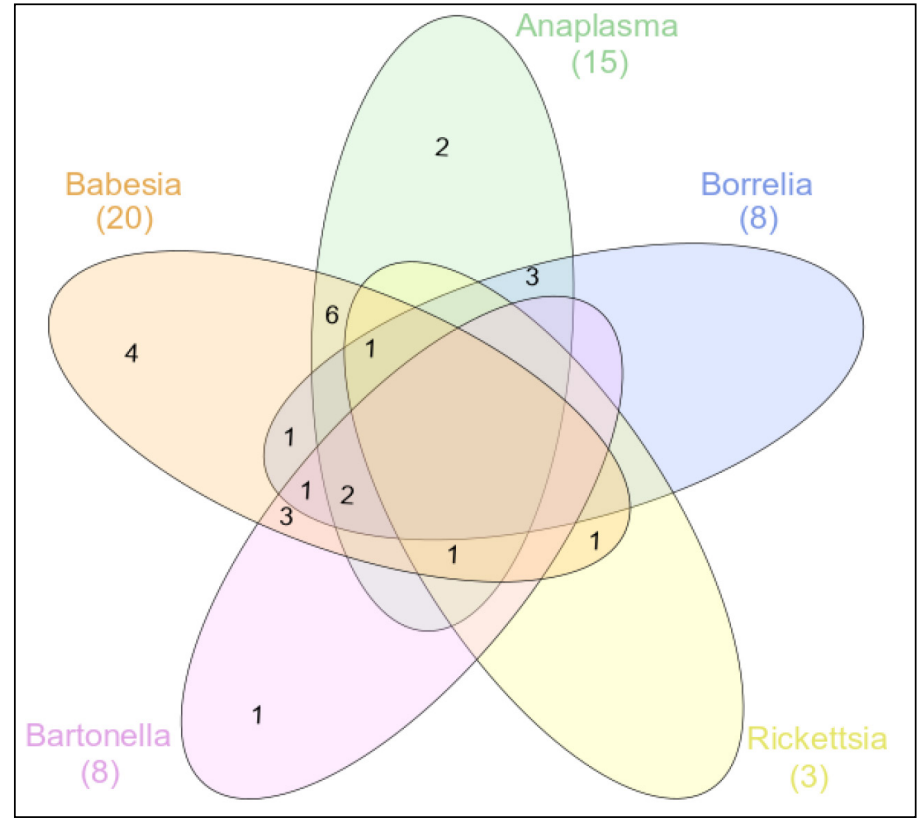

Fig. 2. Venn diagram describing coinfection of red foxes from Lithuania with five different pathogens

(Babesia spp., Borrelia spp. and Bartonella spp.) was detected in one red fox. Coinfection with four different pathogens were detected in four red foxes: one fox was infected with Babesia spp., Anaplasma spp., Borrelia spp. and Rickettsia spp.; one fox was infected with Babe- sia spp., Anaplasma spp., Rickettsia spp. and Bartonella spp.; two foxes were infected with Babesia spp., Anaplasma spp., Borrelia spp. and Bartonella spp.

The overall presence of vector-borne pathogens in red foxes in Europe is shown in Table 4.

Table 4. Review of vector-borne pathogens in European countries

\begin{tabular}{|c|c|c|c|}
\hline Pathogen & Country & Presence in Lithuania & Reference \\
\hline \multirow{3}{*}{ Babesia sp. } & & fox & this study; \\
\hline & Poland & & Karbowiak et al., 2010 \\
\hline & Slovakia & & Koneval et al., 2017 \\
\hline \multirow{4}{*}{ B. canis } & & $\operatorname{dog}$ & Paulauskas et al., 2014 \\
\hline & Portugal & & Cardoso et al., 2013 \\
\hline & Bosnia and Herzegovina & & Hodžić et al., 2015 \\
\hline & Austria & & Hodžić et al., 2018 \\
\hline \multirow{9}{*}{$\begin{array}{c}\text { B. vulpes } \\
\text { (synonyms: } \\
\text { B. microti, B. cf. } \\
\text { microti, B. an- } \\
\text { nae, Theileria } \\
\text { annae) }\end{array}$} & Slovakia & & Koneval et al., 2017 \\
\hline & Austria & & $\begin{array}{c}\text { Duscher et al., 2014; } \\
\text { Hodžić et al., } 2018\end{array}$ \\
\hline & Portugal & & Cardoso et al., 2013 \\
\hline & Hungary & & Farkas et al., 2015 \\
\hline & Bosnia and Herzegovina & & Hodžić et al., 2015 \\
\hline & Germany & & Najm et al., 2014 \\
\hline & Croatia & & Dezdek et al., 2010 \\
\hline & Great Britain & & Bartley et al., 2013 \\
\hline & Italy & & Zanet et al., 2014 \\
\hline B. venatorum & Germany & & Najm et al., 2014 \\
\hline
\end{tabular}


Table 4. (Continued)

\begin{tabular}{|c|c|c|c|}
\hline Pathogen & Country & Presence in Lithuania & Reference \\
\hline \multirow{6}{*}{$\begin{array}{l}\text { Hepatozoon } \\
\text { canis }\end{array}$} & Austria & & $\begin{array}{l}\text { Duscher et al., 2014; } \\
\text { Hodžić et al., } 2018\end{array}$ \\
\hline & Croatia & & Dezdek et al., 2010 \\
\hline & Bosnia and Herzegovina & & Hodžić et al., 2015 \\
\hline & Hungary & & Tolnai et al., 2015 \\
\hline & Slovakia & & Majláthová et al., 2007 \\
\hline & Poland & & Karbowiak et al., 2010 \\
\hline \multirow{10}{*}{$\begin{array}{c}\text { Anaplasma } \\
\text { phagocytophi- } \\
\text { lum }\end{array}$} & & $\begin{array}{l}\text { fox, } \\
\text { dog }\end{array}$ & $\begin{array}{c}\text { this study; } \\
\text { Tamoliūnaite et al., } 2019\end{array}$ \\
\hline & Austria & & Hodžić et al., 2018 \\
\hline & Poland & & Karbowiak et al., 2009 \\
\hline & Italy & & Ebani et al., 2011 \\
\hline & Germany & & Härtwig et al., 2014 \\
\hline & Croatia & & Beck et al., 2014 \\
\hline & Netherlands & & Jahfari et al., 2014 \\
\hline & Hungary & & Tolnai et al., 2015 \\
\hline & Romania & & Dumitrache et al., 2015b \\
\hline & Switzerland & & Hofmann-Lehmann et al., 2016 \\
\hline A. ovis & Italy & & Torina et al., 2013 \\
\hline A. bovis & Croatia & & Beck et al., 2014 \\
\hline A. platys & Portugal & & Cardoso et al., 2015 \\
\hline \multirow{2}{*}{$\begin{array}{c}\text { Candidatus } \\
\text { Neoehrlichia sp. }\end{array}$} & Austria & & Hodžić et al., 2018 \\
\hline & Serbia & & Sukara et al., 2019 \\
\hline Ehrlichia canis & Italy & & Torina et al., 2013 \\
\hline Bartonella spp. & & fox & this study \\
\hline \multirow{3}{*}{ B. rochalimae } & Austria & & Hodžić et al., 2018 \\
\hline & France & & Henn et al., 2009 \\
\hline & Spain & & Gerrikagoitia et al., 2012 \\
\hline $\begin{array}{l}\text { Toxoplasma } \\
\text { gondii }\end{array}$ & Poland & & Karbowiak et al., 2010 \\
\hline Borrelia spp. & & $\begin{array}{l}\text { fox, } \\
\text { dog }\end{array}$ & $\begin{array}{c}\text { this study; } \\
\text { Tamoliūnaitè et al., } 2019 \\
\end{array}$ \\
\hline \multirow{3}{*}{$\begin{array}{l}\text { B. burgdor- } \\
\text { feri s.l. }\end{array}$} & Romania & & (Dumitrache et al., 2015b) \\
\hline & Germany & & Heidrich et al., 1999 \\
\hline & Norway & & Mysterud et al., 2019 \\
\hline $\begin{array}{l}\text { B. burgdor- } \\
\text { feri s.s., } \\
\text { B. lusitaniae, } \\
\text { B. garinii }\end{array}$ & Serbia & & Sukara et al., 2019 \\
\hline Rickettsia spp. & & fox & this study \\
\hline R. helvetica & Switzerland & & Hofmann-Lehmann et al., 2016 \\
\hline R. typhi & Spain & & Lledó et al., 2016 \\
\hline
\end{tabular}


Table 4. (Continued)

\begin{tabular}{|c|c|c|c|}
\hline Pathogen & Country & Presence in Lithuania & Reference \\
\hline R. slovaca & Spain & & Lledó et al., 2016 \\
\hline $\begin{array}{l}\text { R. massiliael } \\
\text { Bar29 }\end{array}$ & Spain & & Ortuño et al., 2018 \\
\hline R. conorii & Spain & & Ortuño et al., 2018 \\
\hline \multirow{2}{*}{$\begin{array}{l}\text { Mycoplas- } \\
\text { ma spp. }\end{array}$} & Slovakia & & Koneval et al., 2017 \\
\hline & Spain & & Millán et al., 2018 \\
\hline $\begin{array}{l}\text { M. haemofelis, } \\
\text { M. haemocanis }\end{array}$ & Slovakia & & Koneval et al., 2017 \\
\hline \multirow{5}{*}{$\begin{array}{l}\text { Dirofilaria } \\
\text { repens }\end{array}$} & & $\operatorname{dog}$ & $\begin{array}{c}\text { Tamoliūnaite et al., 2019; } \\
\text { Sabūnas et al., 2019a }\end{array}$ \\
\hline & Italy & & $\begin{array}{l}\text { Marconcini et al., 1996; } \\
\text { Magi et al., 2007 }\end{array}$ \\
\hline & Slovakia & & Hurníková et al., 2012 \\
\hline & Serbia & & Ćirović et al., 2014 \\
\hline & Romania & & Ionică et al., 2017 \\
\hline \multirow{6}{*}{ D. immitis } & & imported dog & Sabūnas et al., 2019b \\
\hline & Italy & & $\begin{array}{l}\text { Marconcini et al., 1996; } \\
\text { Magi et al., } 2007\end{array}$ \\
\hline & Hungary & & Tolnai et al., 2014 \\
\hline & Serbia & & Penezić et al., 2014 \\
\hline & Romania & & Ionică et al., 2017 \\
\hline & Spain & & Mañas et al., 2005 \\
\hline $\begin{array}{l}\text { Dipetabnema } \\
\text { dracunculoides. }\end{array}$ & Italy & & Marconcini et al., 1996 \\
\hline D. reconditum & Italy & & Marconcini et al., 1996 \\
\hline $\begin{array}{c}\text { Acan- } \\
\text { thocheilonema } \\
\text { reconditum }\end{array}$ & Romania & & Ionică et al., 2017 \\
\hline
\end{tabular}

All studies point to the importance of red foxes as a reservoir of various vector-borne pathogens. Some of them were not detected in this study. However, previous studies conducted in Lithuania showed the presence of Anaplasma spp., Babesia spp., and Dirofilarria sp. in dogs (Paulauskas et al., 2014; Sabūnas et al., 2019a; Sabūnas et al., 2019b; Tamoliūnaitè et al., 2019).

\section{CONCLUSIONS}

Our results demonstrate that vector-borne pathogens are widespread among red foxes in Lithuania. To our knowledge, this is the first report on the detection of infection with Anaplasma spp., Bartonella spp., Rickettsia spp., Borrellia spp. and Babesia spp. in red foxes from Lithuania. Further studies are needed to determine the prevalence and distribution of these vector-borne pathogens in foxes and other carnivores, and their ectoparasites. Mycoplasma spp. and filaroid parasites were not detected in red foxes in our study. Further studies of mycoplasma and filariasis in wildlife carnivores in Lithuania are required.

Received 18 June 2019 Accepted 30 September 2019 


\section{References}

1. Bai Y, Gilbert A, Fox K, Osikowicz L, Kosoy M. Bartonella rochalimae and B. vinsonii subsp. berkhoffii in wild carnivores from Colorado, USA. J Wildlife Dis. 2016; 52(4): 844-9.

2. Baneth G, Cardoso L, Brilhante-Simoes P, Schnittger L. Establishment of Babesia vulpes n. sp. (Apicomplexa: Babesiidae), a piroplasmid species pathogenic for domestic dogs. Parasit Vectors. 2019; 12: 129.

3. Bartley PM, Wright SE, Zimmer IA, Roy S, Kitchener AC, Meredith A, Innes EA, Katzer F. Detection of Neospora caninum in wild carnivorans in Great Britain. Vet Parasitol. 2013; 192(1-3): 279-83.

4. Beck R, Čurik V, Ivana R, Nikica Š, Anja V. Identification of "Candidatus Neoehrlichia mikurensis" and Anaplasma species in wildlife from Croatia. Parasit Vectors. 2014; 7(Suppl 1): O28.

5. Biernat B, Stańczak J, Michalik J, Sikora B, Cieniuch S. Rickettsia helvetica and $R$. monacensis infections in immature Ixodes ricinus ticks derived from sylvatic passerine birds in westcentral Poland. Parasitol Res. 2016; 115(9): 3469-77.

6. Bružinskaitė-Schmidhalter $R$, Šarkūnas $M$, Malakauskas A, Mathis A, Torgerson PR, Deplazes P. Helminths of red foxes (Vulpes vulpes) and raccoon dogs (Nyctereutes procyonoides) in Lithuania. Parasitology. 2012; 139: 120-7.

7. Cardoso L, Cortes HCE, Reis A, Rodrigues P, Simões M, Lopes AP, Vila-Vicosa MJ, TalmiFrank D, Eyal O, Solano-Gallegoe L, Baneth G. Prevalence of Babesia microti-like infection in red foxes (Vulpes vulpes) from Portugal. Vet Parasitol. 2013; 196(1-2): 90-5.

8. Cardoso L, Gilad M, Cortes HC, NachumBiala Y, Lopes AP, Vila-Viçosa MJ, Simões M, Rodrigues PA, Baneth G. First report of Anaplasma platys infection in red foxes (Vulpes vulpes) and molecular detection of Ehrlichia canis and Leishmania infantum in foxes from Portugal. Parasit Vectors. 2015; 8: 144.
9. Chautan M, Pontier D, Artois M. Role of rabies in recent demographic changes in Red Fox (Vulpes vulpes) populations in Europe. Mammalia. 2000; 64(4): 391-410.

10. Checa R, López-Beceiro AM, Montoya A, Barrera JP, Ortega N, Gálvez R, Marino V, González J, Olmeda AS, Fidalgo LE, Miró G. Babesia microti-like piroplasm (syn. Babesia vulpes) infection in red foxes (Vulpes vulpes) in NW Spain (Galicia) and its relationship with Ixodes hexagonus. Vet Parasitol. 2018; 252: 22-8.

11. Chisu V, Leulmi H, Masala G, Piredda M, Foxi C, Parola P. Detection of Rickettsia hoogstraalii, Rickettsia helvetica, Rickettsia massiliae, Rickettsia slovaca and Rickettsia aeschlimannii in ticks from Sardinia, Italy. Ticks Tick Borne Dis. 2017; 8(3): 347-52.

12. Chomel BB, Boulouis HJ, Breitschwerdt EB, Kasten RW, Vayssier-Taussat M, Birtles RJ, Koehler JE, Dehio C. Ecological fitness and strategies of adaptation of Bartonella species to their hosts and vectors. Vet Res. 2009; 40(2): 29.

13. Ćirović D, Penezić A, Pavlović I, Kulišić Z, Ćosić N, Burazerović J, Maletić V. First records of Dirofilaria repens in wild canids from the region of Central Balkan. Acta Vet Hung. 2014; 62: 481-8.

14. Dezdek D, Vojta L, Curković S, Lipej Z, Mihaljević Z, Cvetnić Z, Beck R. Molecular detection of Theileria annae and Hepatozoon canis in foxes (Vulpes vulpes) in Croatia. Vet Parasitol. 2010; 172(3-4): 333-6.

15. Dumitrache MO, D’Amico G, Gherman CM, Matei IA, Ionică AM, Paștiu AI, Balea A, Siko BS, Ionescu DT, Mihalca AD. Prevalence of Anaplasma phagocytophilum and Borrelia burgdorferi sensu lato, in Ixodes ricinus parasitising on red foxes (Vulpes vulpes) from Romania. Bulletin UASVM Veterinary Medicine. 2015a; 72(1): 134-7.

16. Dumitrache MO, Matei IA, Ionică AM, Kalmár Z, D’Amico G, Sikó-Barabási S, Ionescu DT, Gherman CM, Mihalca AD. Molecular detection of Anaplasma phagocytophilum and Borrelia burgdorferi sensu lato genospecies in 
red foxes (Vulpes vulpes) from Romania. Parasit Vectors. 2015b; 8: 514.

17. Duscher GG, Fuehrer HP, Kübber-Heiss A. Fox on the run - molecular surveillance of fox blood and tissue for the occurrence of tickborne pathogens in Austria. Parasit Vectors. 2014; 7: 521.

18. Ebani VV, Verin R, Fratini F, Poli A, Cerri D. Molecular survey of Anaplasma phagocytophilum and Ehrlichia canis in red foxes (Vulpes vulpes) from Central Italy. J Wildlife Dis. 2011; 47(3): 699-703.

19. Edwards CJ, Soulsbury CD, Statham MJ, Ho SYW, Wall D, Dolf G, Iossa G, Baker PJ, Harris S, Sacks BN, Bradley DG. Temporal genetic variation of the red fox, Vulpes vulpes, across western Europe and the British Isles. Quat Sci Rev. 2012; 57(4): 95-104.

20. Farkas R, Takács N, Hornyák A, NachumBiala Y, Hornok S, Baneth G. First report on Babesia cf. microti infection of red foxes (Vulpes vulpes) from Hungary. Parasit Vectors. 2015; 8: 55.

21. Franssen F, Nijsse R, Mulder J, Cremers H, Dam C, Takumi K, van der Giessen J. Increase in number of helminth species from Dutch red foxes over a 35-year period. Parasit Vectors. 2014; 7: 166.

22. Genchi C, Mortarino M, Rinaldi L, Cringoli G, Traldi G, Genchi M. Changing climate and changing vector-borne disease distribution: the example of Dirofilaria in Europe. Vet Parasitol. 2011; 176: 295-9.

23. Genchi C, Rinaldi L, Mortarino M, Genchi M, Cringoli G. Climate and Dirofilaria infection in Europe. Vet Parasitol. 2009; 163: 286-92.

24. Gerrikagoitia X, Gil H, García-Esteban C, Anda P, Juste RA, Barra M. Presence of Bartonella species in wild carnivores of Northern Spain. Appl Environ Microbiol. 2012; 78(3): 885-8.

25. Härtwig V, Schulze C, Pfeffer M, Daugschies A, Dyachenko V. No evidence of Dirofilaria repens infection in red foxes (Vulpes vulpes) and raccoon dogs (Nyctereutes procyonoides) from
Brandenburg, Germany. Parasitol Res. 2016; 115: 867-71.

26. Härtwig V, von Loewenich FD, Schulze C, Straubinger RK, Daugschies A, Dyachenko V. Detection of Anaplasma phagocytophilum in red foxes (Vulpes vulpes) and raccoon dogs (Nyctereutes procyonoides) from Brandenburg, Germany. Ticks Tick Borne Dis. 2014; 5(3): 277-80.

27. Heberle H, Meirelles GV, Da Silva FR, Telles GP, Minghim R. InteractiVenn: a web-based tool for the analysis of sets through Venn diagrams. BMC Bioinformatics. 2015; 16(1): 169.

28. Heidrich J, Schönberg A, Steuber S, Nöckler KL, Schulze P, Voigt WP, Schein E. Investigation of skin samples from red foxes (Vulpes vulpes) in Eastern Brandenburg (Germany) for the detection of Borrelia burgdorferi s. 1. Zentralblatt für Bakteriologie. 1999; 289(5-7): 666-72.

29. Henn JB, Chomel BB, Boulouis HJ, Kasten RW, Murray WJ, Bar-Gal GK, King R, Courreau JF, Baneth G. Bartonella rochalimae in raccoons, coyotes, and red foxes. Emerg Infect Dis. 2009; 15(12): 1984-7.

30. Hodžić A, Alić A, Fuehrer HP, Harl J, WillePiazzai W, Duscher GG. A molecular survey of vector-borne pathogens in red foxes (Vulpes vulpes) from Bosnia and Herzegovina. Parasit Vectors. 2015; 8: 88.

31. Hodžić A, Mrowietz N, Cézanne R, Bruckschwaiger P, Punz S, Habler VE, Tomsik V, Lazar J, Duscher GG, Glawischnig W, Fuehrer HP. Occurrence and diversity of arthropodtransmitted pathogens in red foxes (Vulpes vulpes) in western Austria, and possible vertical (transplacental) transmission of Hepatozoon canis. Parasitology. 2018; 145(3): 335-44.

32. Hofmann-Lehmann R, Wagmann N, Meli ML, Riond B, Novacco M, Joekel D, Gentilini F, Marsilio F, Pennisi MG, Lloret A, Carrapiço T, Boretti FS. Detection of "Candidatus Neoehrlichia mikurensis" and other Anaplasmataceae and Rickettsiaceae in Canidae in Switzerland and Mediterranean countries. Schweiz Arch Tierheilkd. 2016; 158: 691-700. 
33. Hurníková Z, Zale 'sny G, Miterpáková M. Red fox (Vulpes vulpes) as an important reservoir of Dirofilaria repensin Slovak wildlife. In: Grandi G, Kramer L, Genchi C, editors. Proceedings of Third European Dirofilaria Days; 2012; Parma, Italy. p. 68.

34. Ionică AM, Matei IA, D’Amico G, Ababii J, Daskalaki AA, Sándor AD, Enache DV, Gherman CM, Mihalca AD. Filarioid infections in wild carnivores: a multispecies survey in Romania. Parasit Vectors. 2017; 10: 332.

35. Isogai $E$, Isogai $H$, Kawabata $H$, Masuzawa $T$, Yanagihara Y, Kimura K, Sakai T, Azuma Y, Fujii N, Ohno S. Lyme disease spirochetes in a wild fox (Vulpes vulpes schrencki) and in ticks. J Wildl Dis. 1994; 30(3): 439-4.

36. Jahfari S, Coipan E, Fonville M, van Leeuwen A, Hengeveld P, et al. Circulation of four Anaplasma phagocytophilum ecotypes in Europe. Parasit Vectors. 2014; 7(1): 365.

37. Janulaitis Z, Juknelytė S, Griciuvienè L, Paulauskas A. Raccoon dog (Nyctereutes procyonoides) and native predators infection pathogens and parasites comparison. Biologija. 2014; 60(1): 9-15.

38. Kaewmongkol G, Kaewmongkol S, Fleming PA, Adams PJ, Ryan U, Irwin PJ, Fenwick SG. Zoonotic Bartonella species in fleas and blood from red foxes in Australia. Vector Borne Zoonotic Dis. 2011; 11(12): 1549-53.

39. Kanamoto Y, Kotani H, Ogata M, Fukumoto Y. Isolation of mycoplasmas from raccoon dog (Nyctereutes procyonoides viverrinus), fox (Vulpes vulpes japonica) and Japanese badger (Meles meles anakuma). Jpn J Vet Sci. 1981; 43: 267-71.

40. Karamon J, Dąbrowska J, Kochanowski M, Samorek-Pierog M, Sroka J, Różycki M, Bilska-Zajac E, Zdybel J, Cencek T. Prevalence of intestinal helminths of red foxes (Vulpes vulpes) in central Europe (Poland): a significant zoonotic threat. Parasit Vectors. 2018; 11: 436 .

41. Karbowiak G, Majláthová V, Hapunik J, Petko B, Wita I. Apicomplexan parasites of red foxes (Vulpes vulpes) in northeastern Poland. Acta Parasitol. 2010; 55(3): 210-4.

42. Karbowiak G, Víchová B, Majláthová V, Hapunik J, Petko B. Anaplasma phagocytophilum infection of red foxes (Vulpes vulpes). Ann Agric Environ Med. 2009; 16: 71-2.

43. Koneval M, Miterpakova M, Hurnikova Z, Blanarova L, Vichova B. Neglected intravascular pathogens, Babesia vulpes and haemotropic Mycoplasma spp. in European red fox (Vulpes vulpes) population. Vet Parasitol. 2017; 243: 176-82.

44. Lledó L, Serrano JL, Gegúndez MI, GiménezPardo C, Saz JV. Antibodies to Rickettsia spp. and Borrelia burgdorferi in Spanish wild red foxes (Vulpes vulpes). J Wildlife Dis. 2016; 52(1): 122-5.

45. Magi M, Calderini P, Gabrielli S, Dell'omodarme M, Macchioni F, Prati MC, Cancrini G. An update on filarial parasites in Vulpes vulpes of Tuscany (Central Italy). In: Genchi C, Rinaldi L, Cringoli G, editors. Dirofilaria immitis and $D$. repensin dog and cat and human infections. Naples: Rolando editore; 2007. p. 193-4.

46. Magi M, Carderini P, Gabrielli S, Dell'Omodarme M, Macchioni F, Prati MC, Cancrini G. Vulpes vulpes: a possible wild reservoir for zoonotic filarie. Vector Borne Zoonot. 2008; 8: 249-52.

47. Majláthová V, Hurníková Z, Majláth I, Petko B. Hepatozoon canis infection in Slovakia: imported or autochthonous? Vector Borne Zoonotic Dis. 2007; 7(2): 199-202.

48. Mañas S, Ferrer D, Castellà J, López-Martín JM. Cardiopulmonary helminth parasites of red foxes (Vulpes vulpes) in Catalonia, northeastern Spain. Vet J. 2005; 169: 118-20.

49. Marconcini A, Magi M, Macchioni G, Sassetti M. Filariosis in foxes in Italy. Vet Res Comm. 1996; 20: 316-9.

50. Mardosaitè-Busaitienė D, Radzijevskaja J, Balčiauskas L, Bratchikov M, Jurgelvičius V, Paulauskas A. Prevalence and diversity of Bartonella species in small rodents from coastal and continental areas. Sci Rep. 2019; 9: 12349. 
51. Marié JL, Davoust B, Socolovschi C, Mediannikov O, Roqueplo C, Beaucournu JC, Raoult D, Parola P. Rickettsiae in arthropods collected from red foxes (Vulpes vulpes) in France. Comp Immunol Microbiol Infect Dis. 2012; 35(1): 59-62.

52. Márquez FJ, Millán J, Rodríguez-Liéban JJ, García-Egea I, Muniain MA. Detection and identification of Bartonella sp. in fleas from carnivorous mammals in Andalusia, Spain. Med Vet Entomol. 2009; 23(4): 393-8.

53. Messick JB. Hemotrophic mycoplasmas (hemoplasmas): A review and new insights into pathogenic potential. Vet Clin Pathol. 2004; 33(1): 2-13.

54. Millán J, Velarde R, Delicado V, Negre N, Ribas A, Oleaga Á, Llaneza L, Esperón F. High diversity of hemotropic mycoplasmas in Iberian wild carnivores. Comp Immunol Microbiol Infect Dis. 2018; 60: 11-6.

55. Mysterud A, Stigum VM, Jaarsma RI, Sprong H. Genospecies of Borrelia burgdorferi sensu lato detected in 16 mammal species and questing ticks from northern Europe. Sci Rep. 2019; 9: 5088.

56. Najm NA, Meyer-Kayser E, Hoffmann L, Herb I, Fensterer V, Pfister K, Silaghi C. A molecular survey of Babesia spp. and Theileria spp. in red foxes (Vulpes vulpes) and their ticks from Thuringia, Germany. Ticks Tick Borne Dis. 2014; 5(4): 386-91.

57. Ortuño A, Sanfeliu I, Nogueras MM, Pons I, López-Claessens S, Castellà J, Antón E, Segura F. Detection of Rickettsia massiliae/Bar29 and Rickettsia conorii in red foxes (Vulpes vulpes) and their Rhipicephalus sanguineus complex ticks. Ticks Tick Borne Dis. 2018; 9(3): 629-31.

58. Paulauskas A, Radzijevskaja J, Karvelienè B, Grigo A, Aleksandravičienė A, Zamokas G, Babickaitè L, Sabūnas V, Petkevičius S. Detection and molecular characterization of canine babesiosis causative agent Babesia canis in the naturally infected dog in Lithuania. Vet Parasitol. 2014; 205(3-4): 702-6.
59. Penezić A, Selaković S, Pavlović I, Ćirović D. First findings and prevalence of adult heartworms (Dirofilaria immitis) in wild carnivores from Serbia. Parasitol Res. 2014; 113: 3281-5.

60. Razanske I, Rosef O, Radzijevskaja J, Bratchikov M, Griciuviene L, Paulauskas A. Prevalence and co-infection with tick-borne Anaplasma phagocytophilum and Babesia spp. in red deer (Cervus elaphus) and roe deer (Capreolus capreolus) in Southern Norway. Int J Parasitol Parasites Wildl. 2019; 8: 127-34.

61. Rishniw M, Barr SC, Simpson KW, Frongillo MF, Franz M, Dominguez Alpizar JL. Discrimination between six species of canine microfilariae by a single polymerase chain reaction. Vet Parasitol. 2006; 135(3-4): 303-14.

62. Sabūnas V, Radzijevskaja J, Sakalauskas P, Petkevičius S, Karvelienè B, Žiliukienė J, Lipatova I, Paulauskas A. Dirofilaria repens in dogs and humans in Lithuania. Parasit Vectors. 2019a; 12(1): 177.

63. Sabūnas V, Radzijevskaja J, Sakalauskas P, Paulauskas A. First report of heartworm (Dirofilaria immitis) infection in an imported dog in Lithuania. Helminthologia. 2019b; 56(1): 57-61.

64. Saeed I, Maddox-Hyttel C, Monrad J, Kapel CMO. Helminths of red foxes (Vulpes vulpes) in Denmark. Vet Parasitol. 2006; 139: 168-79.

65. Sasaki M, Ohta K, Matsuu A, Hirata H, Ikadai H, Oyamada T. A molecular survey of $M y$ coplasma haemocanis in dogs and foxes in Aomori Prefecture, Japan. J Protozool Res. 2008; 18: 57-60.

66. Schipper J, Chanson JS, Chiozza F, Cox NA, Hoffmann M, et al. The status of the world's land and marine mammals: diversity, threat, and knowledge. Science. 2008; 322: 225-30.

67. Scott DM, Berg MJ, Tolhurst BA, Chauvenet ALM, Smit GC, Neaves K, Lochhead J, Baker PJ. Changes in the distribution of red foxes (Vulpes vulpes) in urban areas in Great Britain: findings and limitations of a mediadriven nationwide survey. PLoS ONE. 2014; 9(6): e99059. 
68. Simón F, Siles-Lucas M, Morchón R, GonzálezMiguel J, Mellado I, Carretón E, MontoyaAlonso JA. Human and animal dirofilariasis: the emergence of a zoonotic mosaic. Clin Microbiol Rev. 2012; 25: 507-44.

69. Sukara R, Juwaid S, Ćirović D, Penezić A, Mihaljica $\mathrm{D}$, Veinović $\mathrm{G}$, Radojičić S, Hodžić A, Duscher GG, Tomanović S. Candidatus Neoehrlichia sp. (FU98) and Borrelia burgdorferi Sensu Lato in Red Foxes (Vulpes vulpes) from Serbia. Acta Veterinaria. 2019; 69(3): 312-24.

70. Sumithra TG, Chaturvedi VK, Susan C, Siju SJ, Rai AK, Harish C, Sunita SC. Mycoplasmosis in wildlife: a review. Eur J Wildl Res. 2013; 59: 769-81.

71. Tamoliūmaitè D, Radzijevskaja J, Sabūnas V, Paulauskas A. Prevalence of zoonotic mosquito-borne and tick-borne pathogens in domestic dogs from Lithuania. ICSB 3rd international conference, Kaunas, Lithuania, 2019: 208.

72. Teacher AGF, Thomas JA, Barnes I. Modern and ancient red fox (Vulpes vulpes) in Europe show an unusual lack of geographical and temporal structuring, and differing responses within the carnivores to historical climatic change. Evol Bio. 2011; 11: 214.

73. Tolnai Z, Sréter-Lancz Z, Sréter T. Spatial distribution of Anaplasma phagocytophilum and Hepatozoon canis in red foxes (Vulpes vulpes) in Hungary. Ticks Tick Borne Dis. 2015; 6(5): 645-8.

74. Tolnai Z, Széll Z, Sproch Á, Szeredi L, Sréter T. Dirofilaria immitis: an emerging parasite in dogs, red foxes and golden jackals in Hungary. Vet Parasitol. 2014; 203: 339-42.

75. Torina A, Blanda V, Antoci F, Scimeca S, D’Agostino R, Scariano E, Piazza A, Galluzzo P, Giudice E, Caracappa S. A molecular survey of Anaplasma spp., Rickettsia spp., Ehrlichia canis and Babesia microti in foxes and fleas from Sicily. Transbound Emerg Dis. 2013; 60: 125-30.

76. Truyen U, Müller T, Heidrich, Tackmann K, Carmichael LE. Survey on viral pathogens in wild red foxes (Vulpes vulpes) in Germany with emphasis on parvoviruses and analysis of a DNA sequence from a red fox parvovirus. Epidemiol Infect. 1998; 121(2): 433-40.

77. Varanat M, Maggi RG, Linder KE, Breitschwerdt EB. Molecular prevalence of Bartonella, Babesia, and Hemotropic Mycoplasma sp. in dogs with splenic disease. J Vet Intern Med. 2011; 25(6): 1284-91.

78. Víchová B, Bona M, Miterpáková M, Kraljik J, Čabanová V, Nemčíková G, Hurníková Z, Oravec M. Fleas and ticks of red foxes as vectors of canine bacterial and parasitic pathogens, in Slovakia, Central Europe. Vector Borne Zoonotic Dis. 2018; 18(11): 611-9.

79. Vos A. Oral vaccination against rabies and the behavioural ecology of the red fox (Vulpes vulpes). J Vet Med B. 2003; 50: 477-83.

80. Zanet S, Trisciuoglio A, Bottero E, de Mera IG, Gortazar C, Carpignano MG, Ferroglio E. Piroplasmosis in wildlife: Babesia and Theileria affecting free-ranging ungulates and carnivores in the Italian Alps. Parasit Vectors. 2014; 7: 70.

81. Zienius D, Sereika V, Lelešius R. Rabies occurrence in red fox and raccoon dog population in Lithuania. Ekologija. 2007; 53(1): 59-64.

\section{Povilas Sakalauskas, Indrè Lipatova, Jana Radzijevskaja, Algimantas Paulauskas \\ RUDŲJŲ LAPIŲ (Vulpes vulpes) UŽSIKRĖTI- MAS PATOGENAIS LIETUVOJE}

\section{Santrauka}

Šio tyrimo tikslas buvo patikrinti laisvai gyvenančių rudųjų lapių užsikrètimą skirtingais vektorių pernešamais patogenais Lietuvoje. Iš viso molekuliniais metodais ištirta 31 lapè iš trijų Lietuvos apskričių. Nustatyti 5 skirtingu šeimų patogenai 83,9 \% tirtų lapių: Anaplasma spp., Bartonella spp., Rickettsia spp., Borrellia spp. ir Babesia spp. Šio tyrimo metu Mycoplasma spp. ir Dirofilaria spp. lapèse neaptikta.

Raktažodžiai: Vulpes vulpes, Anaplasma spp., Bartonella spp., Rickettsia spp., Borrellia spp., Babesia spp., Mycoplasma spp., Dirofilaria spp. 